\title{
The Dutch vocational education and training system
}

Citation for published version (APA):

Verhagen, A. M. C. (2014). The Dutch vocational education and training system. ROA. ROA Technical Reports No. 005 https://doi.org/10.26481/umarot.2014005

Document status and date:

Published: 01/01/2014

DOI:

10.26481/umarot.2014005

Document Version:

Publisher's PDF, also known as Version of record

\section{Please check the document version of this publication:}

- A submitted manuscript is the version of the article upon submission and before peer-review. There can be important differences between the submitted version and the official published version of record.

People interested in the research are advised to contact the author for the final version of the publication, or visit the DOI to the publisher's website.

- The final author version and the galley proof are versions of the publication after peer review.

- The final published version features the final layout of the paper including the volume, issue and page numbers.

Link to publication

\footnotetext{
General rights rights.

- You may freely distribute the URL identifying the publication in the public portal. please follow below link for the End User Agreement:

www.umlib.nl/taverne-license

Take down policy

If you believe that this document breaches copyright please contact us at:

repository@maastrichtuniversity.nl

providing details and we will investigate your claim.
}

Copyright and moral rights for the publications made accessible in the public portal are retained by the authors and/or other copyright owners and it is a condition of accessing publications that users recognise and abide by the legal requirements associated with these

- Users may download and print one copy of any publication from the public portal for the purpose of private study or research.

- You may not further distribute the material or use it for any profit-making activity or commercial gain

If the publication is distributed under the terms of Article $25 \mathrm{fa}$ of the Dutch Copyright Act, indicated by the "Taverne" license above, 


\section{The Dutch vocational education and training system}

Annelore Verhagen

\section{ROA Technical Report}

ROA-TR-2014/5

Researchcentrum voor Onderwijs en Arbeidsmarkt | ROA

Research Centre for Education and the Labour Market | ROA 


\title{
The Dutch vocational education and training system
}

\author{
Annelore Verhagen
}

ROA-TR-2014/5

November 2014

Research Centre for Education and the Labour Market Maastricht University

P.O. Box 616, 6200 MD Maastricht, The Netherlands

$\mathrm{T}+31433883647 \mathrm{~F}+31433884914$

secretary-roa-sbe@maastrichtuniversity.nl www.roa.nl 


\section{Introduction to the Dutch school system}

In the Netherlands, education is compulsory for pupils aged 5 to 16 . Within secondary education, pupils can opt for one of three different tracks (see also Figure 1):

- The pre-vocational track (VMBO), which takes 4 years after which the student should have obtained ISCED ${ }^{\mathrm{a}}$ level 2. The pre-vocational track prepares pupils for upper secondary vocational education $(\mathrm{MBO})^{1}$.

- The pre-college track (HAVO), also called senior general secondary education, which takes 5 years after which students should have obtained ISCED level 3A. This track prepares pupils for higher professional education in vocational colleges $(\mathrm{HBO})^{2}$, but the content of the HAVO study program is not vocational.

- The pre-university track (VWO), which takes 6 years and prepares its pupils for further education in university instead of vocational colleges.

Compulsory education ends at the pupil's sixteenth birthday, at which point HAVO and VWO pupils are still in the midst of their study programs, and VMBO pupils just graduated or are about to graduate. To prevent pupils from dropping out and to establish a minimum credential for young people that confers eligibility for the labour market, the Dutch Ministry of Education, Culture and Science introduced the concept of a starting qualification (startkwalificatie) in the year $2000^{3}$. From this moment on, education is also compulsory for students aged 16-17 who have not yet attained a diploma that is considered a starting qualification, i.e. a diploma on at least ISCED level 3A or level 3C Long (VWO, HAVO, or MBO level 2 and up); the so called 'qualification duty' (kwalificatieplicht $)^{\mathrm{b}}$. This means that HAVO and VWO pupils are obliged to continue their program until they turn 18 or obtain their diploma, and that VMBO graduates (who are usually younger than 18) are obliged to continue in further education. Nearly all VMBO graduates indeed continue education, the majority of which continues in upper secondary vocational education (MBO). Even though education is no longer compulsory for them, the majority of HAVO and VWO graduates also continue education after graduating. The majority of HAVO graduates continue in vocational colleges (HBO), and the majority of VWO graduates continue in university education.

Figure 1 illustrates the structure of the Dutch educational system and the possible movements from one track to another. The VET providers are highlighted in grey. We decided to focus this chapter on only one of the three VET providers, namely MBO, since this seems to be most comparable to the focus of the desk-based study of the Irish FET sector, i.e. providers on ISCED levels 2-4, excluding secondary schools ${ }^{\mathrm{c}}$.

\footnotetext{
${ }^{\text {a }}$ In this document we refer to the ISCED 2011 scale.

${ }^{\mathrm{b}}$ Students under 23 who leave education without a starting qualification are considered to be early schoolleavers.

${ }^{c}$ The desk-based study of the Irish FET sector focusses on all providers of accredited provision below NFQ level6 that takes place outside of second level schools (though including VEC schools). According to Cedefop ${ }^{4}$, NFQ level 6 would be in between ISCED 1996 levels 4 and 5B, and NFQ level 5 would be more or less comparable to ISCED 1996 level 4. Secondary education in Ireland is said to be comparable to ISCED level 2. This means that the document on the Irish FET sector focuses on ISCED 2011 levels 2-4, excluding secondary education. This would correspond to the Dutch MBO levels 1-4.
} 


\section{Figure 1.}

\section{The Dutch educational system}

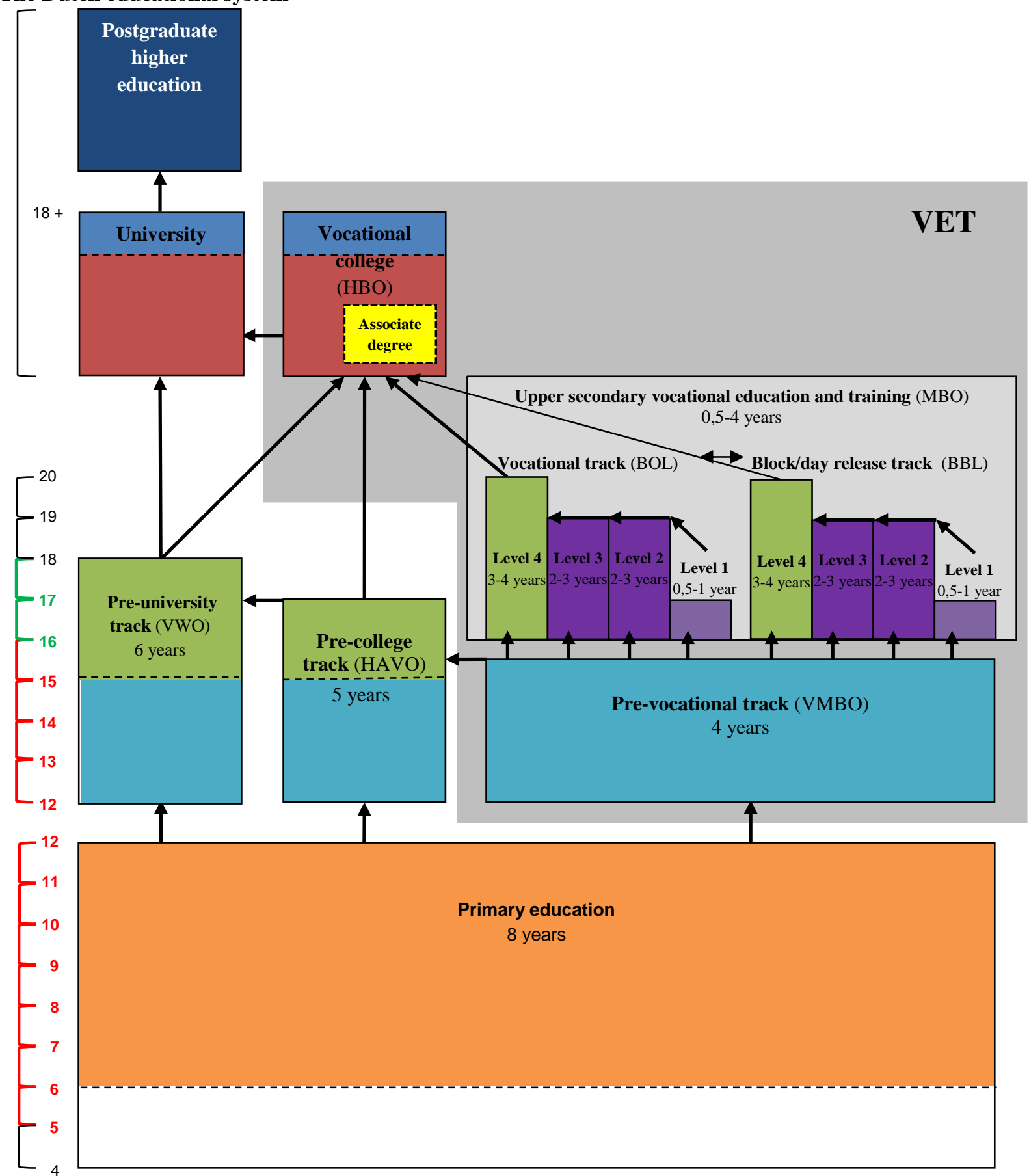

\begin{tabular}{|l|}
\hline ISCED 8 \\
\hline ISCED 7 \\
\hline ISCED 6 \\
\hline ISCED 5 \\
\hline ISCED 4 \\
ISCED 3A \\
\hline ISCED 3C long \\
\hline ISCED 3C short \\
\hline ISCED 2 \\
\hline ISCED 1 \\
\hline ISCED 0 \\
\hline
\end{tabular}

Doctoral or equivalent

Master or equivalent

Bachelor or equivalent

Short cycle tertiary education

Post secondary non tertiary education

Upper secondary education

Upper secondary education

Upper secondary education

Lower secondary education

Primary education

Early childhood education

[ Non-compulsory education

[ Compulsory education
Postgraduate higher education (PhDs)

University Master / HBO Master

University Bachelor / HBO Bachelor

$\mathrm{HBO}$ associate degree

MBO level 4 specialist

VWO year 4-6 /HAVO year 4-5 / MBO level 4

MBO level 2 / MBO level 3

MBO level 1

VWO year 1-3 / HAVO year 1-3 /VMBO year 1-4

Primary education year 3-8

Primary education year 1-2

[ Qualification duty (extended compulsory education) 


\section{Context}

The Dutch educational system is highly stratified from secondary education onwards ${ }^{3}$, and this also applies to MBO. Each MBO course can be followed in two different learning pathways, called the vocationally educating learning pathway (beroepsopleidende leerweg: $B O L$ ) and the vocationally guiding learning pathway (beroepsbegeleidende leerweg: $B B L$ ). MBO-BOL courses are school-based and practical training takes up between $20 \%$ and $60 \%$ of the course. MBO-BBL courses are work-based; practical training takes up more than $60 \%$ of the course ${ }^{5}$. Before they start their study program, first-year MBO-BBL pupils are fully responsible to find an apprenticeship, for which they have to apply. In principle all courses should be offered in both pathways (though in practice this is not always the case), and both pathways are (supposed to be) completely equal with regard to labour market opportunities and qualifications ${ }^{6}$. MBO courses can be taken at four different qualification levels, from ISCED level 3C short up and including ISCED level $4^{7}$. Finally, MBO courses are offered in four sectors: Personal/social services and health care, Technology, Economics, and Agriculture and the natural environment (also called 'green education'). The latter sector is funded by the Ministry of Economic Affairs ${ }^{8}$. Another defining feature of the Dutch education system is freedom of education. Schools and institutions have a great degree of educational and administrative autonomy ${ }^{9}$.

According to the $\mathrm{OECD}^{10}$ the Dutch approach to vocational education and training has the following strengths and challenges ${ }^{\mathrm{d}}$ :

\section{Strengths}

- The Netherlands has a strong and well-funded VET system with a large proportion of each student cohort following vocational studies and substantial public and private resources dedicated to VET.

- Work-based learning forms a large part of Dutch VET both in MBO-BOL and MBOBBL. VET in the Netherlands has good labour market outcomes with low youth unemployment rates.

- There is a well-developed system to engage social partners both in policy formulation and implementation.

\section{Challenges}

- While the Dutch economy has greatly benefited from strong work-based learning in the vocational education and training system, challenges remain in reaping its full benefits, as demographic decline and the popularity of academic education put pressure on the VET system. Continued economic challenges may weaken employers' willingness to offer work placements, and policy reforms may also present new challenges.

- Teachers are the most valuable resource in any teaching institution, but their skills have to be updated regularly. Currently entry from industry into teaching in VET schools is relatively uncommon, given regulatory restrictions. This limits the capacity of schools to keep up with changing industry practice, and to take on new recruits in response to a coming wave of retirements.

\footnotetext{
${ }^{d}$ Only the strengths and challenges that are about MBO are cited.
} 
- The lowest level of upper secondary VET (MBO 1), faces considerable challenges. It concentrates young people with disadvantaged backgrounds and yields comparatively poor labour market outcomes. Such a concentration of educational problems may further exacerbate these problems. However, it encompasses a very diverse student body which calls into question the underlying rationale for tracking.

- Current provision may not fully meet labour market demand for higher level vocational skills. Enrolment in associate degrees is low, and there are few options for the graduates of MBO to upskill other than the academic route.

Allen and van der Velden ${ }^{11}$ point out that in the $21^{\text {st }}$ century the polarization of jobs due to technological developments sharply affects the number of jobs in the middle of the earnings distributions, like clerks, assembly line workers, and other jobs that mainly involve routine tasks. This means that MBO graduates are increasingly vulnerable on the labour market.

\section{Stated underlying rational and objectives}

Formally, all MBO study programs are designed to prepare their pupils for labour market entrance. Graduates with a diploma on MBO level 1 are not considered to be eligible for the labour market though; they do not have a 'starting qualification'. This means that for MBO level 1 courses, besides the emphasis on the labour market, there is also an emphasis on continuing education. Some of the MBO level 1 graduates (the ones younger than 18) are even still legally obliged to continue education. Not all pupils are capable to continue or successfully complete education on MBO level 2 though, due to e.g. cognitive or social reasons. For them, MBO level 1 study programs also work as a social inclusion mechanism. Another difference between MBO levels is that only holders of a level $4 \mathrm{MBO}$ certificate may go on to higher education in vocational colleges (HBO) ${ }^{5}$. Therefore, MBO level 4 study programs are relatively more focussed on further education, whereas MBO level 3 study programs are relatively more focussed on the labour market.

There is no formal difference in the emphasis between the school-based track (BOL) and the work-based track (BBL) in $\mathrm{MBO}$; they are both providing the same qualifications and are emphasising on labour market provision by providing practical training. However, since the MBO-BBL students already had to apply for an apprenticeship of three or four days a week before starting their courses, the enrolment in MBO-BBL courses is much more dependent on the demand on the labour market than the enrolment in the school-based MBO-BOL. Also, after graduation, the majority of MBO-BOL students continues in education, whereas the majority of MBO-BBL graduates start (continue) to work.

\section{Governance structure}

The Dutch education system combines a centralized education policy with the decentralized administration and management of schools ${ }^{12}$. At the national level the governance of MBO consists of determining the content of programs in terms of goals and competencies in 'qualification files' (see paragraph 6), strategic planning and development, the distribution of funding to public institutions and monitoring the teaching and exam quality. These national 
governance tasks lie with the Ministry of Education, Culture and Science and partially (for the green education) with the Ministry of Economic Affairs ${ }^{13}$. The responsibility for monitoring the quality lies with the Education Inspectorate, which is part of the Ministry of Education, Culture and Science. Inspections of schools and programs take place every few years, with the frequency depending on the previous inspection results ${ }^{13}$.

The Dutch VET system is designed to be able to adapt to specific regional labour market demands. At the regional level, MBO schools therefore have full autonomy in determining which study programs they offer and what these study programs look like in terms of examination and teaching. They also have extensive autonomy with regard of programming, planning and the exact allocation of budgets ${ }^{13}$.

The role of social partners, including trade unions and employers' associations, is that they are involved in evaluating if existing and new programs meet labour market needs ${ }^{14}$. For professions at the MBO level, these social partners (co-)decide what each profession contains, what the key tasks and work processes are and what someone should be capable of doing in order to perform the profession when entering the labour market ${ }^{14}$.

\section{Funding arrangements}

The role of the state in funding MBO is the funding by the Ministry of Education, Culture and Science, except for the green education, which is being funded by the Ministry of Economic Affairs. If schools meet the quality standards imposed by the Ministry, they virtually automatically qualify for funding ${ }^{15}$.

MBO-students who are under 18 do not have to pay tuition or course fees. Students who are over 18 and who follow a course in MBO-BOL (the school-based track) have to pay tuition fees to the school. If students are over 18 and follow a course in MBO-BBL (the work-based track) they have to pay course fees, but the amount depends on the level of the course ${ }^{16}$ (see table 1). On top of the tuition and course fees, students have to pay for 'school costs', such as learning resources (books, readers, etc.) and (if needed) work clothes or -shoes. The amount of school costs varies between programs, but usually costs are between $€ 500$ and $€ 1000$ a year $^{17}$.

Table 1.

Tuition and course fees in MBO (school year 2013/2014) ${ }^{18}$

\begin{tabular}{|l|l|l|}
\hline & MBO-BOL tuition fees & MBO-BBL course fees \\
\hline Level 1 and 2 & $€ 1.090$ & $€ 226$ \\
\hline Level 3 and 4 & $€ 1.090$ & $€ 549$ \\
\hline
\end{tabular}

MBO-BOL students between 18 and 30 years old are entitled to a student grant, a supplementary grant (depending on the parental income), a public transport discount card and a loan. If they follow a program on level 1 or 2 , all except for the loan is a gift. If they follow a program on level 3 or 4 , all is performance-related, which means that they have to repay the grant, supplementary grant, costs of the public transport card, and of course the loan, if they fail to complete the program ${ }^{17}$. 


\section{Planning}

All MBO courses lead to a specific occupational skill or qualification ${ }^{19}$. The system is competence-based, and the competences MBO students should have at the end of their study program is described in 'qualification files' (kwalificatiedossiers). New qualifications are developed at a national level in cooperation with representatives of employer's associations by the 17 sectoral 'knowledge centres' that work together in the so-called Samenwerking Beroepsonderwijs en Bedrijfsleven ( $S B B$ ) ('collaboration vocational education and industry'), After the development, the content of these qualification files is decided by the Ministries of Education, Culture and Science, but schools have full autonomy in deciding how students can achieve those qualifications (teaching and examination). Because of this, and the fact that employers' representatives are involved in evaluating the labour market relevance of new and existing study programs, the system is able to respond to both national and regional changes in economic and social environments and priorities.

The increasing youth unemployment since the beginning of the recent economic crisis resulted in 2009 in the introduction of a policy program to reduce and prevent youth unemployment (Aanpak Jeugdwerkloosheid). An important part of this policy is the so-called School Ex Program, which aims to stimulate MBO graduates to continue education, and to try to persuade pupils who enter MBO (mostly VMBO graduates) who want to register for a study program with bad labour market perspectives to change their choice towards a study program with (relatively) good labour market perspectives.

In order to improve the quality of vocational education in MBO the Ministry of Education, Culture and Science also introduced a policy program called Focus op Vakmanschap 20112015 ('focus on craftsmanship 2011-2015'). The policy focuses on intensifying and shortening MBO study programs, improving the quality of the exams, professionalizing teachers, reducing the number of qualifications and study programs (there were 627 qualifications in 2011 when the policy program was introduced), and improving the alignment of the supply of vocational training to the needs of the regional industry. In order to improve the flow from MBO to higher levels of education (e.g. in vocational colleges (HBO)), the Ministry also introduced intensified Dutch language and math courses for all MBO students, and obligatory English courses for pupils in MBO level 4. With regard to the governance structure the regulation and supervision has been tightened and the satisfaction of the industry with MBO becomes one of the foundations for funding ${ }^{20}$.

\section{The role and involvement of employers}

As was described in paragraph 4, employers are involved in evaluating if new and existing study programs meet labour market needs, and in deciding what the key competences are that belong to a certain profession. Since 2012, this is organized on the national level in a foundation called Samenwerking Beroepsonderwijs en Bedrijfsleven (SBB) ('collaboration vocational education and industry'), which advices the Ministry of Education, Culture and Science in developing the qualification structure. Based on the information provided by knowledge centers which represent 17 different occupational sectors, SBB also publishes information by region and by MBO course on the chance of getting an internship and the 
chance of getting a job after graduation. SBB represents almost 70 MBO-schools and 200.000 recognized training companies ${ }^{21}$.

\section{Monitoring}

The Education Inspectorate officially monitors the quality of teaching, the quality of examinations and the regularity of expenditure, financial management and the financial position of $\mathrm{MBO}$ schools $^{22}$. Apart from this, the schools are themselves required to set up and maintain a quality assurance system.

Even though the Ministry of Education, Culture and Science has legally always been able to implement quite extensive monitoring of MBO study programs, it only recently (since the beginning of 2012) started making plans for using more of its power in this regard, by introducing a bill on macro efficiency ${ }^{23}$. This is related to the increasing political attention for reducing youth unemployment. Up to now, schools have an automatic incentive to only provide those courses in MBO-BBL (the work-based track) for which there is a demand on the labour market, because first year MBO-BBL students are obliged to have found a job before they start their course. This incentive is however less prominent for the provision of MBO-BOL courses, because these are relatively more school-based. The Ministry is currently evaluating in what way the monitoring of the labour market relevance and macro-efficiency of MBO study programs can be improved, by investigating what the criteria should be for inadequate labour market relevance and macro-efficiency. If a study program is not meeting the criteria, the Ministry can decide to shut the program down. Up to now, schools only had to prove that a new study program was relevant for the regional labour market when the program was being created. Now, they will also have to prove this after creation.

\section{Data infrastructure}

There are several institutions which collect data on MBO. The main data source on students is the Basisregister Onderwijs (BRON) ('basic register for education'), in which all students are registered. This register is being managed by DUO, which is part of the Ministry of Education, Culture and Science. The data consists of the entire school history of each student (i.e. which study program on which school, when diplomas were obtained, etc.). Because BRON also contains the identity numbers of the students, it can be linked to other register data, so that background variables like age, gender and residence can be identified. This can of course not be done by all research institutions; The Statistics Netherlands is the only one who is allowed to link these register data. The BRON data are the main source of information on i.e. numbers of students and graduates, progression to further education and dropouts/early school-leavers.

Besides the register data, there is also a lot of data being collected through surveys. Below, several data collections are described. This list is however not complete; there are many institutions collecting data on VET.

- The organization that represents the interests of MBO students called Jongeren Organisatie Beroepsonderwijs (JOB) ('youth organization vocational education') annually 
collects data on the satisfaction of MBO students with regard to the education they received. The results are supposed to enable student councils and management to improve the education within $\mathrm{MBO}^{24}$.

- The Knowledge Center for Vocational Training and Labour Market (KBA) carries out independent and scientific policy research in the field of VET and the labour market, which serves as a source of information for various governmental and private organizations $^{25}$.

- Every year, the Research Centre for Education and the Labour Market (ROA) carries out a survey among school-leavers (among which are MBO graduates), on their transition from school to a subsequent course or to the labour market ${ }^{26}$. The results are an important source of information for the Ministry of Education, Culture and Science and the Ministry of Social Affairs.

- As described in paragraph 7, the SBB (in which employers are represented) collects data on the chance of getting an internship and getting a job after graduation. This information is one of the sources used by schools and the Ministry of Education, Culture and Science to assess the labour market relevance of study programs.

\section{Comparative summary}

When reading the document describing the Irish FET system, we noticed that an important strength of the Irish system compared to the Dutch, is that it has a well-integrated scheme for unemployed persons, by means of the VTOS program. In the Netherlands, educational and training opportunities for unemployed are not well-integrated in the VET system; the focus lies mainly on people who are either in school or work. Here lies a lesson to be learned for the Dutch education system.

However, compared to the Dutch system, we also noticed a weakness of the Irish FET system. Reading the document, we noticed that the Irish system is rather fragmented, with several different providers and awarding bodies, providing minor and major awards, certificates and diplomas, and a proportion of provision not leading to any formal accreditation. In the Netherlands, VET is (compared to the Irish system) a highly structured system with only a few providers and all programs leading to formal qualifications. Dutch politicians even tend think that there are too many qualifications in $\mathrm{MBO}$, and are therefore trying to reduce the number: fewer but broader qualifications are the aim. There were 627 qualifications in 2011. 


\section{Literature}

\footnotetext{
${ }^{1}$ Government of the Netherlands (n.d.). Pre-vocational education (VMBO). Retrieved from http://www.government.nl/issues/education/pre-vocational-education-vmbo

${ }^{2}$ Government of the Netherlands (n.d.). VWO and HAVO. Retrieved from http://www.government.nl/issues/education/vwo-and-havo
}

${ }^{3}$ R. van der Velden, C. Büchner \& T. Traag (2014), The Dutch School system, In: F. Weerman, V, van der Geest, C. Bijleveld (eds.), Criminal Behaviour from School to the Workplace: Untangling the Complex Relations Between Employment, Education and Crime, Routledge, pp. 179 - 183.

${ }^{4}$ CEDEFOP (2013). Spotlight on VET Ireland. Retrieved from http://www.cedefop.europa.eu/EN/Files/8044_en.pdf

${ }^{5}$ Government of the Netherlands (n.d.). Secondary vocational education (MBO). Retrieved from http://www.government.nl/issues/education/secondary-vocational-education-mbo

${ }^{6}$ SBB (2012). Dutch educational system [electronic version], p 2.

${ }^{7}$ Ministry of Education, Culture and Science (2012). Key Figures 2008-2012, pp 100 \& 208.

${ }^{8}$ Ministry of Education, Culture and Science (2012). Key Figures 2008-2012, p 208.

${ }^{9}$ Eurypedia (2013). Netherlands: Political, Social and Economic Background and Trends. Retrieved from https://webgate.ec.europa.eu/fpfis/mwikis/eurydice/index.php/Netherlands:Political,_Social_and_Economic Bac kground_and_Trends

${ }^{10}$ OECD (2013). A skills beyond school review of the Netherlands: Draft for comment October 12013 , p 4.

${ }^{11}$ Allen, J. \& Velden, R.K.W. van der (2011). Skills for the 21 st Century: Implications for Education, p 9. Maastricht: Research Centre for Education and the Labour Market.

${ }^{12}$ Eurypedia (2013). Netherlands: Overview. Retrieved from https://webgate.ec.europa.eu/fpfis/mwikis/eurydice/index.php/Netherlands:Overview

${ }^{13}$ OECD (2013). A skills beyond school review of the Netherlands: Draft for comment October 12013 , p 11.

${ }^{14}$ Rijksoverheid (n.d.). Mbo-examens. Retrieved from http://www.rijksoverheid.nl/onderwerpen/middelbaarberoepsonderwijs/mbo-examens

${ }^{15}$ Eurypedia (2012). Netherlands: Funding in Education. Retrieved from https://webgate.ec.europa.eu/fpfis/mwikis/eurydice/index.php/Netherlands:Funding in_Education

${ }^{16}$ Eurypedia (2012). Adult Education and Training Funding. Retrieved from https://webgate.ec.europa.eu/fpfis/mwikis/eurydice/index.php/Netherlands:Adult_Education_and Training_Fun ding

${ }^{17}$ Rijksoverheid (n.d.). Kosten mbo-opleiding. Retrieved from http://www.rijksoverheid.nl/onderwerpen/middelbaar-beroepsonderwijs/kosten-mbo-opleiding

${ }^{18}$ Rijksoverheid (n.d.). Wat is de wettelijke hoogte van het lesgeld, cursusgeld en collegegeld? Retrieved from http://www.rijksoverheid.nl/onderwerpen/middelbaar-beroepsonderwijs/vraag-en-antwoord/wat-is-de-wettelijkehoogte-van-het-lesgeld-cursusgeld-en-collegegeld.html

${ }^{19}$ Eurypedia (2013). Netherlands: Assessment in Vocational Secondary Education (MBO). Retrieved from https://webgate.ec.europa.eu/fpfis/mwikis/eurydice/index.php/Netherlands:Assessment_in_Vocational_Secondar y_Education_(MBO)

${ }^{20}$ Kamerbrief d.d. 16-02-2011: Actieplan mbo Focus op Vakmanschap 2011-2015. Reference number: 270414.

${ }^{21} \mathrm{SBB}$ (n.d.). Introductie. Retrieved from http://www.s-bb.nl/introductie.html 
${ }^{22}$ Eurypedia (n.d.). Netherlands: Quality Assurance in Adult Education and Training. Retrieved from https://webgate.ec.europa.eu/fpfis/mwikis/eurydice/index.php/Netherlands:Quality Assurance in Adult Educat ion_and Training

${ }^{23}$ Ministerie van Onderwijs, Cultuur en Wetenschap (2013). Wetsvoorstel macrodoelmatigheid mbo. Retrieved from http://www.internetconsultatie.nl/macrodoelmatigheid_mbo

${ }^{24} \mathrm{JOB}$ (n.d.). Job monitor. Retrieved from http://job-monitor2014.nl/

${ }^{25} \mathrm{KBA}$ (n.d.). Onderzoek en advies rond vraagstukken op het snijvlak van beroepsonderwijs en arbeidsmarkt. Retrieved from http://www.kenniscentrum-ba.nl/

${ }^{26}$ ROA (2013). School-leavers between education and the labour market 2012: Facts and figures. Maastricht: Research Centre for Education and the Labour market. 